\title{
Saved by seaweeds: phyconomic contributions in times of crises
}

\author{
Ole G. Mouritsen ${ }^{1}$ (D) Prannie Rhatigan ${ }^{2} \cdot$ M. Lynn Cornish $^{3}$ (D) Alan T. Critchley ${ }^{4}$ (D) $\cdot$ José Lucas Pérez-Lloréns $^{5}$ (I)
}

Received: 25 June 2020 / Revised and accepted: 10 September 2020 / Published online: 7 November 2020

(C) Springer Nature B.V. 2020

\begin{abstract}
Seaweeds (macroalgae) are, together with microalgae, main contributors to the Earth's production of organic matter and atmospheric oxygen as well as fixation of carbon dioxide. In addition, they contain a bounty of fibres and minerals, as well as macroand micronutrients that can serve both technical and medicinal purposes, as well as be a healthy and nutritious food for humans and animals. It is therefore natural that seaweeds and humans have had a myriad of interwoven relationships both on evolutionary timescales as well as in recent millennia and centuries all the way into the Anthropocene. It is no wonder that seaweeds have also entered and served as a saviour for humankind around the globe in many periods of severe needs and crises. Indeed, they have sometimes been the last resort, be it during times of famine, warfare, outbreak of diseases, nuclear accidents, or as components of securing the fabric of social stability. The present topical review presents testimony from the history of human interaction with seaweeds to the way humankind has, over and over again, been 'saved by seaweeds'. It remains a historical fact that in extreme conditions, such as shortage and wars, humans have turned to seaweeds in times of 'needs must' and created new opportunities for their uses in order to mitigate disasters. Lessons to be learned from this history can be used as reminders and inspiration, and as a guide as how to turn to seaweeds in current and inevitable, future times of crises, not least for the present needs of how to deal with changing climates and the pressing challenges of sustainable and healthy eating.
\end{abstract}

Keywords Seaweeds $\cdot$ Crisis $\cdot$ War $\cdot$ Famine $\cdot$ Nuclear accidents $\cdot$ Human diseases $\cdot$ Unemployment

\section{Introduction: seaweeds and humankind}

Seaweeds are macroalgae that constitute a very heterogeneous and diverse group of multicellular organisms. Being photosynthetic, seaweeds together with the microalgae are responsible for producing most of the atmosphere's oxygen and fixing most of the carbon dioxide (Chapman 2013). Comprising more than 12,000 species, seaweeds are found in all climatic zones on the planet and they can be harvested sustainably in the wild and/or farmed by (mari)aquaculture using various phyconomic practices. Considering the omnipresence of seaweeds in coastal areas, it is maybe not surprising that these organisms have played an important role for life on the planet, not least human beings during evolutionary time scales, as well the present times.

It is now believed that our close ancestors, Homo erectus, evolved near aqueous basins and not on the hot African grasslands (Crawford and Marsh 1989; Cunnane et al. 2014). Apart from archaeological finds, a strong argument for the human lineage evolving near shores of big lakes or oceans is that it
Ole G. Mouritsen

ole.mouritsen@food.ku.dk

Prannie Rhatigan

irishseaweedkitchen@gmail.com

M. Lynn Cornish

lcornish@acadian.ca

Alan T. Critchley

alan.critchley2016@gmail.com

José Lucas Pérez-Lloréns

joselucas.perez@uca.es
1 Department of Food Science, Taste for Life, Design and Consumer Behaviour, University of Copenhagen, 26 Rolighedsvej, DK-1958 Frederiksberg, Denmark

2 Irish Seaweed Kitchen, Streedagh House, Streedagh, Grange, Co., Sligo, Ireland

3 James S. Craigie Research Centre, Acadian Seaplants Limited, Cornwallis, NS B0S1A0, Canada

4 Verschuren Centre for Sustainability in Energy and Environment, Cape Breton University, Sydney, Nova Scotia, Canada

5 Instituto Universitario de Investigación Marina (INMAR), Universidad de Cádiz, Av. República Saharaui s/n. 11510, Puerto Real, Cádiz, Spain 
was only here that they would find enough food supplies with the necessary and sufficient amounts of the essential, nutritional building blocks that are the prerequisite for building a complex neural system and a brain with the very large brain/body weight ratio $(2.1 \%)$ that is a singular characteristic of humans (Cunnane et al. 2014). In particular, these building blocks were essential fatty acids, the super-unsaturated omega- 3 and omega- 6 fatty acids, as well as a range of micronutrients, such as iodine, iron, copper, zinc and selenium (Cornish et al. 2017). Indeed, it is the algae, not animals, fungi or plants, that uniquely possess the necessary enzyme systems required to synthesize large amounts of super-unsaturated fatty acids. This is where algae came into the picture and entered an essential entanglement with human evolution towards today's Homo sapiens.

Since that time, humans have directly or indirectly depended on algae, including seaweeds. First as a food source, most prominently manifested along the 'kelp highway' leading to the peopling of the Americas (Erlandson et al. 2007), later also as a useful building material (Mouritsen 2013), feed for livestock (Rajauia 2015), and medicinal aids (Fleurence and Levine 2016), as well as a range of modern-time technical applications (Pérez-Lloréns et al. 2018). In some parts of the world, the tradition for using seaweeds as a valuable food has been maintained until present times (Mouritsen 2013; O’Connor 2017; PérezLloréns et al. 2018), whereas in other places, this use was seemingly forgotten, and seaweeds have mostly served as various raw materials for a number of practical uses and extracts - many times in distanced ways where most people would not know that a specific application was actually based on a particular type of seaweed, e.g. as a food ingredient, a hydrogel, a medicinal aid or a fire repellent.

Moreover, the close relationships between seaweeds and human beings can also be seen to be reflected in a rich culture, mythology, folklore and poetry (O'Connor 2017; Pérez-Lloréns et al. 2020). Importantly in the present context, humankind and human societies have time and time again turned to seaweeds in times of crises to take advantage of what this diverse and ancient, polyphyletic assemblage of marine, photosynthetic organisms can offer in order to meet the basic needs of sustenance, alleviate suffering from diseases, and secure health, well-being, and survival at critical stages of human history. With the severe scale of global problems that humans and societies now face with pandemics, climate change and the need for sustainable food sources and supplies, we may once again turn our collective and focused attention to seaweeds.

\section{Seaweeds during times of famine and hardship}

- "They [the Irish] were starving, eating old cabbage leaves, roadside weeds, rotten turnips, while on the coast itself the population lived on dillisk (dulse) and raw limpets". (Woodham-Smith 1962)

- "Potatoes, children, seaweeds": an old Irish aphorism about women's preferences reveal the importance of seaweed in daily life.

Various specific seaweeds have been an important part of the diet in many Eastern countries for millennia, but only sparsely exploited and eaten in the Western world. However, it did not always use to be like that, and coastal dwellers and communities have to some extent used seaweeds as food/feed both for themselves and their livestock (Sauvageau 1920; Mouritsen 2013; O’Connor 2017; Pérez-Lloréns et al. 2018). Ironically, in contrast to the veneration of seaweeds and their benefits in Eastern countries, those seaweeds in Europe have unfortunately been branded as being associated with poor people and famine.

Ireland is an interesting example in this connection. Harvesting seaweeds is a long-standing tradition there. The farmers, sheep farmers and fishers with their lands adjoining the coast have for hundreds of years enjoyed the rights to harvest the seaweeds of the foreshore and intertidal zone in order to feed themselves and their domestic animals and also to build organic materials and soil as well as fertilize their plots of land and in particular their potato beds. In spite of the long tradition of exploiting marine algae in Ireland (Guiry and Morrison 2013), most people, unfortunately, presently associate them with poverty and the starvation resulting from the Great Famine that devastated the country in 1845-1849 (Woodham-Smith 1962; Gallagher 1982).

The poor population in the western part of Ireland was at that time completely dependent on their crop of potatoes, which taken together with dairy were nutritionally adequate for living. An Irish peasant would in the middle of the nineteenth century consume $3-5 \mathrm{~kg}$ of potatoes every day. When the potato blight hit at the end of the 1840 s, disaster was imminent. Sadly, about one million died during the Great Famine. As a direct consequence, from 1848 to 1950, more than 6 million Irish men and women emigrated, and the population declined from 4.4 million in 1861 to 2.8 million in 1961. During the famine, access to the foreshore with a rich vegetation of nutritionally dense seaweeds became the 'last resort' for the starving population-so it is no wonder why seaweeds later became associated with the troubled time of famine and as the poor people's food.

The relation between poor coastal Irish populations and seaweeds is beautifully reflected in the novel Trinity (Uris 1976) and in Robert J. Flaherty's Man of Aran ethno-fiction documentary (1934) which chronicled the daily life of the inhabitants of these islands on the west coast of Ireland. It showed the struggle for survival of a family of islanders and the harshness of their work on the coast. In order to grow just a few potatoes, they had to gouge out holes in the rock and fill 
them with the little soil they were able to find. This was then supplemented with the seaweeds transported by the women in large baskets on their backs (Fig. 1). This story was then glamorised in the Hollywood movie The Field.

The revival of the Irish seaweed cuisine for purposes of health and pleasure has since been described by Prannie Rhatigan (Rhatigan 2009, 2018).

Brown seaweeds (kelp) contain large amounts of iodine (Teas et al. 2004). This precious compound that could be used as an antiseptic and ointment, as well as source for silver iodide for photographic plates, was the basis for a cottage industry at the Irish coast providing a little extra and welcome source of income for the poor. Seaweeds were dried and burned into ashes from which both iodine and potash for glass production could be recovered. Harper (2014) writes that a new suit or frock worn to church in Carnlough in western Ireland brought the remark, 'The kelp is shining on you'.

Similarly, in Iceland, when food was in short supply and there was a risk of famine, the Icelanders probably resorted to species that were hardier than the dulse (Palmaria palmata) they would more commonly consume (Kristjánsson 1980). The most probable candidates were carrageen (Chondrus crispus) and winged kelp (Alaria esculenta), which were normally used only for animal fodder. The consumption of seaweeds was, however, for many centuries linked mostly to times of hardship. On the Faroe Islands, there is even a saying about a person who dies in poverty: 'He was laid in his grave with a piece of seaweed in his mouth' (Mouritsen 2013).

The dwellers of some coastal regions in South America have also consumed seaweeds during periods of scarcity. For instance, macocho (Gigartina spp.) is typical of Peru, and luche (Pyropia columbina) and cochayuyo (Durvillaea antarctica) have been consumed in Chile since preColumbian times (Pérez-Lloréns et al. 2018). The first record of seaweed used by man for food and/or medicine was found in Monte Verde (Chile) going 14.000 years back (Dillehay

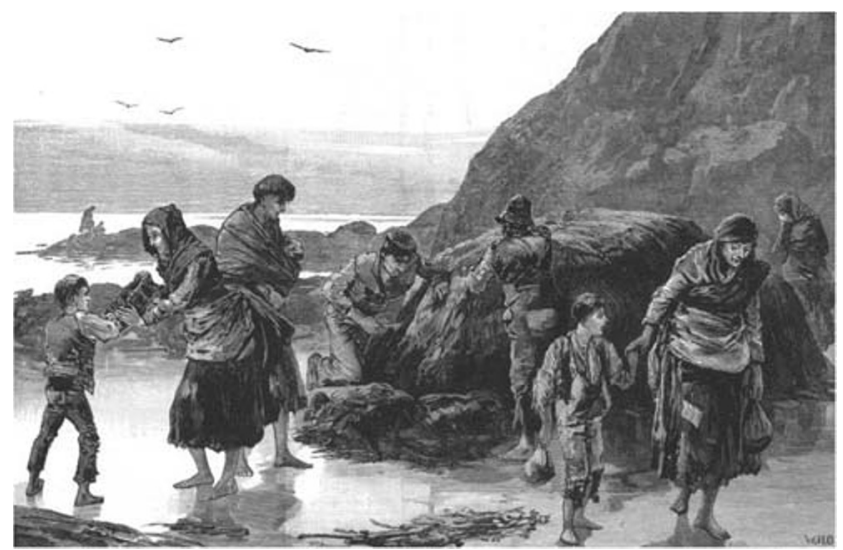

Fig. 1 Poor families collecting seaweeds at the West Coast of Ireland during the Great Famine, 1845-1849 et al. 2008). Seaweeds may yet again in this region come to poor people's rescue and cochayuyo is promoted to combat hunger in poor areas in southern Chile (Milesi 2018).

\section{Seaweeds during times of war and international conflicts}

With their many exceptional and unique material properties and chemical components, seaweeds have not surprisingly come to rescue during times of warfare. An example from Antiquity describes how Muslim scientists and naval commanders in the early eight century found a way to use seaweed to avoid damage to their vessels from the devastating so-called Greek Fire that the Byzantine fleet used in order to put enemy vessels on fire (Fig. 2). An Alexandrian 'Abd al-Rahmān understood how to extract a material called algin from the brown alga Cystoseira barbata which he then used to fireproof cloth. He used this cloth to cover the ships protecting them from the Greek Fire (Khalilieh and Boulos 2006).

During WW1 and WW2, many materials for technical applications were in short supply, and in some cases, the available biomass from natural populations of various seaweeds provided a temporary rescue for manufacturing of hydrogels and fine chemicals. Indeed, seaweed extract for the benefit of plant production is at least in part attributed to the use of liquid seaweed extracts as a darkening agent for camouflage netting. It was 'water soluble' so in the rain it dropped off and was found to enhance growth or plants around the points of use (Craigie 2011).

During WW1, the Californian kelp industry manufactured large quantities of potassium chloride, iodine and acetone as well as ethyl acetate, ethyl propriate, ethyl butyrate and 'kelpchar' (a decolorizing carbon of exceptional quality) (Sanford 1958; Woodward 1965). Extracts from Laminaria species were used to seal grenades. Alginic acid was used as a binder in the manufacture of cartridge primers, and extracts from available red seaweeds were used to replace foreign gums that were in short supply (Chapman 1950). Germany

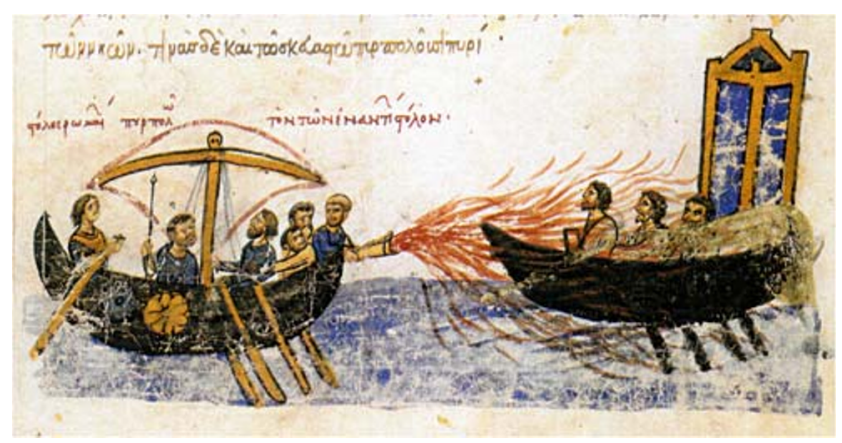

Fig. 2 A Byzantine ship uses Greek Fire against a ship of the rebel. Twelfth century illustration from the Madrid Skylitzes. (Public Domain) (https://bit.ly/30TwEKM) 
placed an embargo on the import of potash to the USA, and in order to have enough for gun powder production, the Californian kelp forests were able to provide materials to produce this indispensable component (Neushul 1989) (Fig. 3).

The carrageenans extracted from the red seaweed Chondrus crispus (Irish moss) were used during WW1 to disguise the bitter taste of some medicines and as sore throat relievers for soldiers who had been gassed (Kreig 1966).

During WW2, alginates were also used to produce camouflage paint and artificial silk material for parachutes (Long 2014). Agar was one of the strategic materials, owing to certain of its unique gel-forming properties that allowed its use in the preparation of solid culture media in bacteriology (Sanford 1958). In many countries, there was a shortage of agar, mostly because its supply from Japan was cut off. This stimulated a development of using local seaweeds to produce related polysaccharides for hydrogels. In New Zealand, girls were encouraged by the local newspaper (Auckland Star 1942) to collect 'the right seaweed' to produce agar for the hospitals. A similar turning to local seaweeds took place in Denmark right after the war where a shortage of imported agar enabled a whole new industry springing up to produce what was termed Danish agar derived from the red seaweed called 'black carrageen', Furcellaria lumbricalis/fastigiata (due to its colour when dried) (Breinholst 1963). Today, this might be referred to as 'disruptive technology' but is an indication of phyconomic ingenuity spurred on by needs. Black carrageen contains furcelleran that is a polysaccharide having properties similar to, but not quite exactly the same as, agar. The production went on from 1946 to 1960 and led to the development of
Fig. 3 The Hercules Powder Company in Southern California (South Bay Historical Society) which harvested kelp to produce potash to manufacture gun powder during WW1. (CC BY 2.0) (https://bit.ly/2AGryXM)
The Literary Digest for December 21, 1918 S1

\section{From War to Peace}

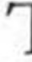

Patisfy the demands of war the Hercules Powder Company has cut over 621,000 tons of and-a-half years. This has been converted into chemicals necessary to the manufacture of smokeless powder, black powder, shell lacquers, and coating for aeroplane wings. Over $\$ 5,000,000$ have been expended in the great plant at San Diego, Cal., in which the chemicals are extracted from this giant seaweed.

The development of a new source of these chemicals -potash, acetone, and other solvents-was vital to the triumph of democracy. Now that victory is assured, these and others are at the disposal of the industries of peace.

Kelp yields many useful products in addition to those which have been necessary to the prosecution of the war. Many of them are well-known to the drug and chemical trades. Some of them have never been produced in commercial quantities before. Others that are now made only on a laboratory scale can be readily turned out in quantity if a demand is found.

We ask all manufacturen and chemisis who believe that success in the new industrial era which ia upcis as demands new methots and new ideas, to consider these chenicas in the licht of pessible applications to processes in which they are interested. If you ate materials does not suezes an immovement in you greduct, er maving in its manufacture. If you ane a chemist, does not some thing in the lat at the right offer poribilities for new acomplish. ments in your profestion?

In either cave, our Research Dejartmert is at your Almoval the working out methods for appbing any of these chemicals to jour working out methods for applint any of these chemicals to jour needs, of

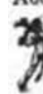

Chemical Salos Department HERCULES POWDER, CO. Wilmington, Delaware
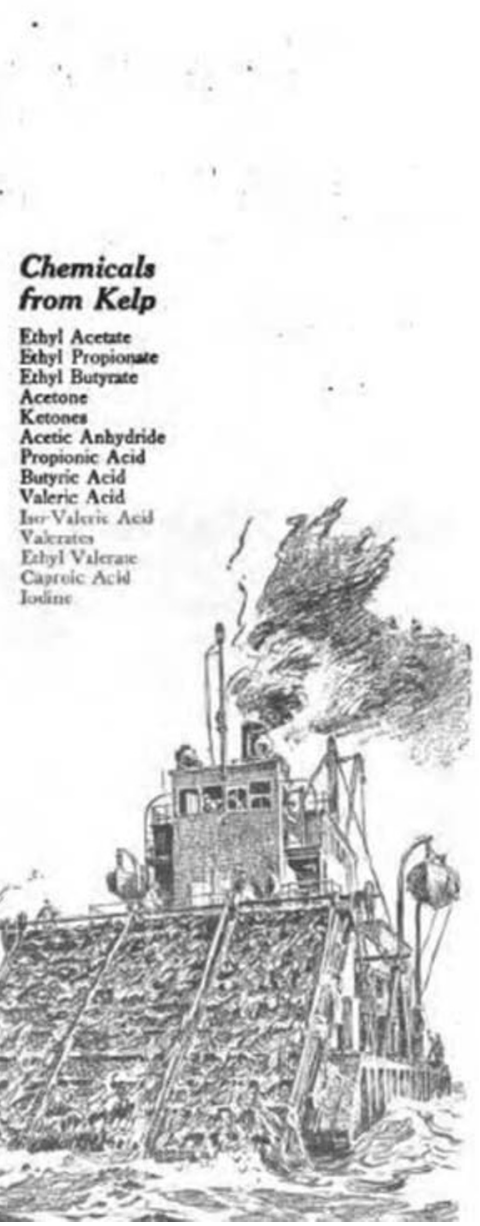
the company called Copenhagen Pectin, with exports to other parts of Europe and the USA to be used in food and textile industries. It was so successful that the activities basically wiped out the Danish populations of Furcellaria. Today, the economic utilisation of this genus of seaweed is limited to some Baltic states and Eastern Canada (Prince Edward Island).

The WW2 medic Major George Blaine was the first clinician to investigate the interaction of wound tissue with alginates, and to realize their potential as absorbers of exudate. He used them on burn wounds in the Far East and carried out clinical studies when the war was over (Blaine 1946). The scarcity of food during WW2 raised people's interest in seaweeds as food. German occupation troops in Norway built two bakeries to make seaweed bread (Schwimmer 1955). An amusing instance of confusing a cryptogamist for a cryptogramist led to the recruitment of the seaweed expert Geoffrey Tandy to work on the secret WW2 project in Britain to crack the code of the German Naval Enigma machine whereby a seaweed scientist so to speak helped win the war (Freeborn 2014).

\section{Seaweeds and nuclear accident}

As mentioned above, some seaweeds contain substantial amounts of iodine (Teas et al. 2004), in particular brown seaweeds of the Laminariales (Mouritsen et al. 2019a). Iodine from the diet accumulates in the thyroid and is essential for its healthy functioning. This observation renders certain seaweeds a useful source for iodine, and consumption of marine food for iodine supply has at times been critical for large populations around the world (Mouritsen 2013) (Fig. 4). The thyroid gland of a normal adult contains in steady-state of approximately $8 \mathrm{mg}$ of iodine, of which ca. $1-2 \mu \mathrm{g}$ per kilogram of body weight is utilized each day. For a person weighing $75 \mathrm{~kg}$, this translates into a daily requirement of

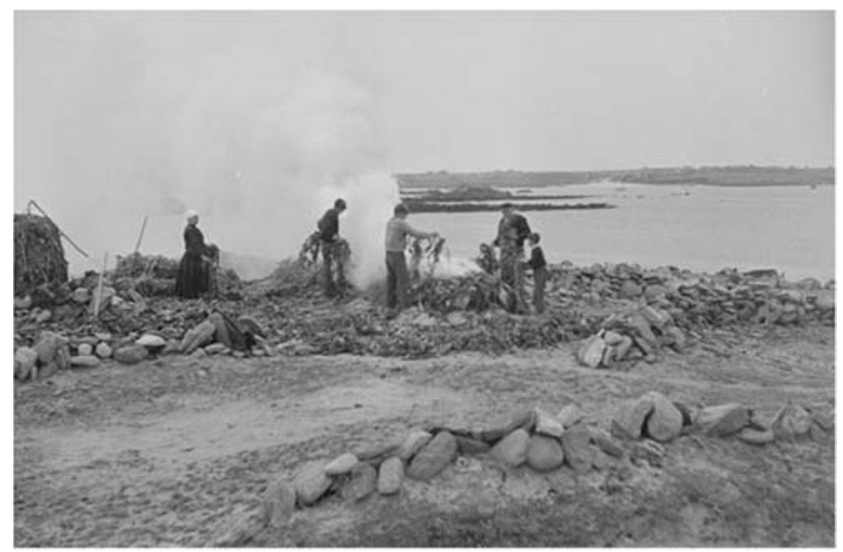

Fig. 4 Burning of kelp at the coast of Northern Brittany. The ashes contained various salts like potash and iodine from the brown seaweeds
$150 \mu \mathrm{g}$ of iodine which must be ingested with food and drink. The daily requirement can be greater if that iodine is displaced by other substances, especially chlorine, which is added to drinking water in some places.

Accumulation of iodine in the thyroid can cause a critical problem if it is replaced by the radioactive isotope iodine- 131 . This isotope has been released accidentally by nuclear power plants and/or used in various forms of radiotherapy. Iodine131 accumulates in the thyroid and later in the reproductive organs. Human consumption of iodine tablets, or iodine derived from brown seaweeds, can help to reduce the uptake of radioactive iodine by the thyroid gland via displacement of the radioactive isotope due to a surplus of the common isotope iodine-127. Iodine supplements constitute an essential part of the protection against radiation poisoning that could result from an accident at a nuclear plant or in conjunction with the explosion of a nuclear weapon. Evidence of uses for seaweeds in such critical situations, used as a prophylactic measure, can be traced to increased sales of kelp products following the disasters at the Chernobyl (in 1986) and Fukushima (in 2011) nuclear power plants (Braverman et al. 2014). Preparing the necessary stocks for iodine-131 emergencies is also relevant for managing terrorism, accidental nuclear errors and ultimately nuclear warfare (Braverman et al. 2014).

\section{Seaweeds and livelihood in developing countries}

Many developing countries and particularly their coastal regions suffer from unemployment and societal structures which make it very difficult for families to arrange for their daily needs. In many cases, looking after the family (health, welfare, education, etc.) and especially the children is left to women. There are examples where particular types of seaweeds have come to rescue to these women and played a pivotal socioeconomic role in the survival of their families. In small, family-owned businesses, women engage in seaweed aquaculture particularly of Kappaphycus spp. and Eucheuma spp. in the Western Indian Ocean and South-East Asia, including Africa, India and South-east Asia. Many more women than men are involved in the farming of seaweeds in shallow, intertidal basins. These 'seaweed women' have made significant phyconomic advances in the sustainability of seaweed farming for more than four decades and their dedication, patience and resilience illustrate tenacity in the face of crises (BayLarsen et al. 2014; Periyasamy et al. 2014; Msuya and Hurtado 2017; Hurtado et al. 2019).

As a specific example, in Zanzibar, many women support their families entirely by farming algae on strings in shallow waters (Forsberg and Vestling 2018). Women produced $412 \mathrm{t}$ of seaweed in the year 2016/17 which was equivalent to $80 \%$ of the total seaweed production in Zanzibar whereas men 
produced only 103 t equivalent to $20 \%$ of the total production. The income from selling the crop to the carrageenan companies improves the livelihood of the families and helps to pay school fees for their children during the year (Kalumanga 2018). Recently, changing climate has worsened the conditions for seaweed farming and hence eroded women's status in Zanzibar (Ott 2018). In Malaysia, governmental capacity building programmes have been set up to improve skills and knowledge among local seaweed cultivators, in particular women, in order stimulate rural community development (Kunjuraman et al. 2019). Coastal and sustainable livelihood through seaweed mariculture has also been valued in Indonesia (Aslan et al. 2018; Waters et al. 2019). It should however be remarked that due to cultural differences in tradition for what kind of work men and women traditionally engage in, there are differences in the way family farming is done in different regions (Fig. 5).

\section{Seaweeds, human health and disease prevention}

Medicinal uses of seaweeds, as well as potential health benefits of consuming seaweeds, or seaweed-derived products

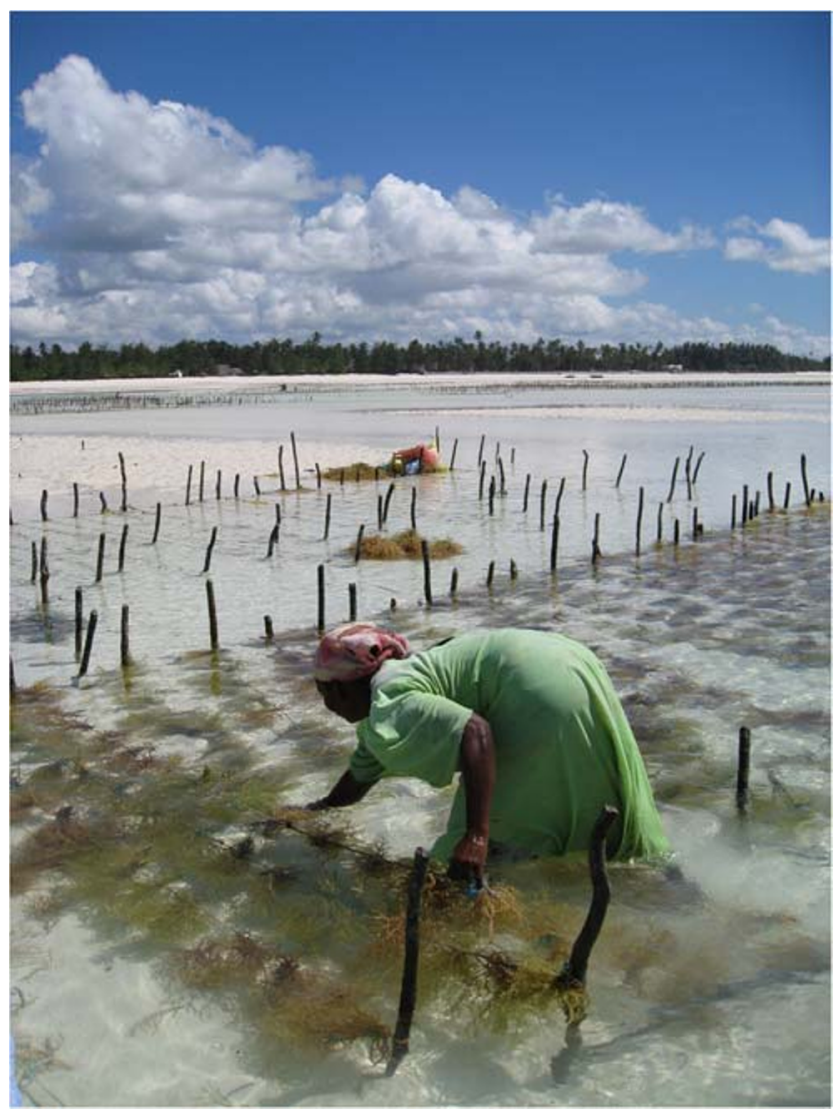

Fig. 5 Women cultivate Spinosum (Eucheuma denticulatum) in Zanzibar for carrageenan production. Courtesy of Marie Frost have been extensively reviewed in the scientific literature and are indicative of their importance and growing applications, both in general (Fleurence and Levine 2016; Déléris et al. 2016), as well as in specific cases, such as heart- and coronary diseases (Cornish et al. 2015; Cardoso et al. 2015; Murai et al. 2019), brain and neural development and diseases (Cornish et al. 2017; Guo et al. 2019; Schepers et al. 2020; Hannan et al. 2020), irritable bowel syndrome and the human microbiome (Mathieu et al. 2018; Cornish et al. 2019), prevention and treatment of various cancers (Mamvar et al. 2013; Jiang and Shi 2018), viral infections (Domínguez 2013; Mazalovska and Kouokam 2018), and parasite infections (Shafiq et al. 2018), as well as diabetes and obesity (Sharifuddin et al. 2015; Husni 2018; Attjioui et al. 2020; Bermanoa et al. 2020). Furthermore, various bioactive compounds of seaweed origin, such as secondary metabolites (Holdt and Kraan 2011; Kim 2012; Collins et al. 2016; Rosa et al. 2020), nutraceuticals (Domínguez 2013; Shannon and Abu-Ghannam 2019) and other functional ingredients (Peñalver et al. 2020), have been suggested for judicious use as prophylactics and interventions in disease prevention. Recently, it has been pointed out that seaweeds with their many bioactive compounds should be considered as a rescue to cure the so-called forgotten diseases, not least tropical deceases, that are pestering 1.4 billion people in the poorest parts of the world, such as insect-borne infections, leishmaniasis, helminth infections and trypanosomiasis (Shafiq et al. 2018; Falkenberg et al. 2019; Freile-Pelegrín and Tasdemir 2019).

Important elements discovered in the ashes of brown seaweeds, such as bromine by Balard in 1826 (Smith 1926) and prior to that the discovery of iodine by Courtois in 1811, were very early considered as pharmaceuticals and used for treatments in various medical applications. Bromine has recently been identified as an essential trace element for humans (McCall et al. 2014), and the bromide salts were once a major medical sedative before replacement by shorter acting drugs. Iodine, of course, is well known to be an essential nutrient, important for thyroid health and cognitive aptitude (Zimmermann 2009). It furthermore plays a role in antisepsis and wound management (Selvaggi et al. 2003). Globally, iodine deficiency is the greatest preventable cause of mental impairment (WHO 2007), and the opportunity to supplement daily diets with specific seaweeds could have a huge positive impact on the human population (Fig. 6).

In his famous book The Sea (La Mer), the French historian Jules Michelet wrote in 1861 (Michelet 2013):

- For three very sound and sufficient reasons I love and I bless that vast vegetation; small or large, that vegetation has three lovely qualities:

- Firstly, how innocent are all its members: no one of them all is poisonous. Vainly in the whole marine vegetation shall you search for one poisonous plant. Seek in every 


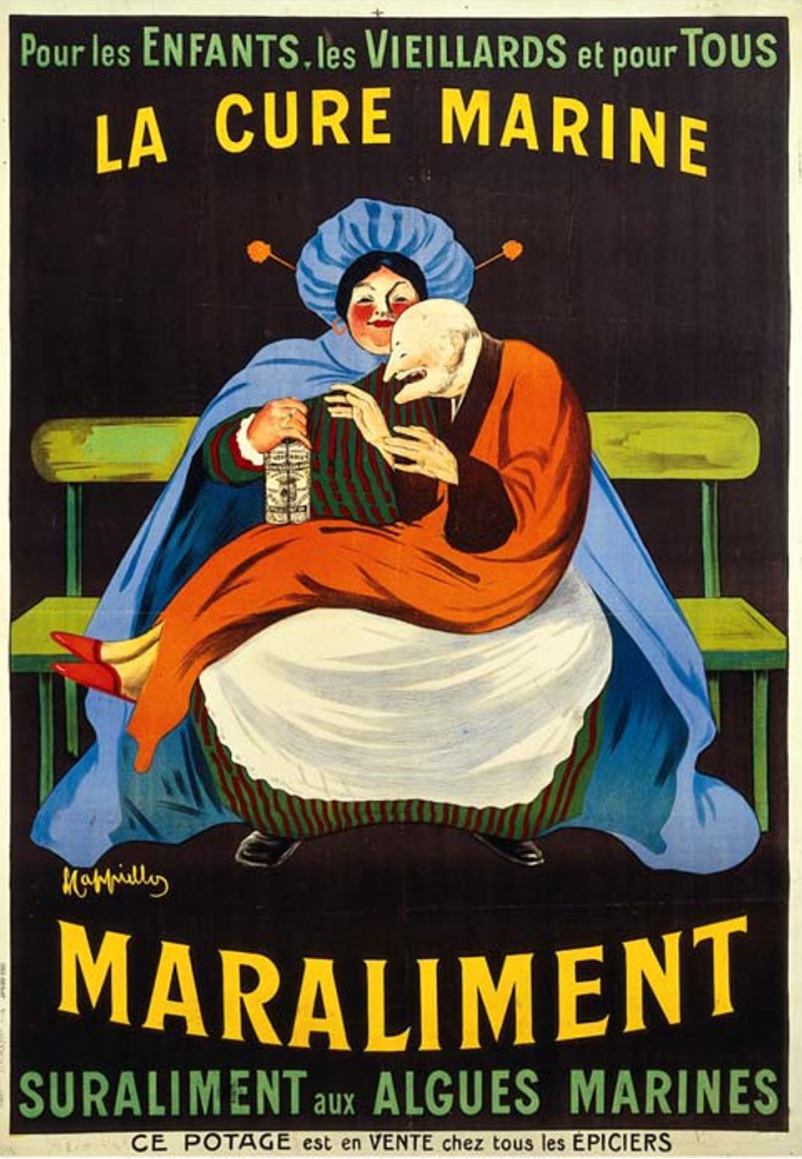

Fig. 6 French advertisementpraising marine algae as a marine cure for sick children and elderly. (CC BY 4.0) (https://bit.ly/3dahByZ)

sea, and in every latitude, you will find the vegetation wholesome, genial, a blessing and a mercy.

- Those innocent plants ask for nothing more than to nourish or to heal animality. Many of them, the laminaires (Laminariales), for instance, contain a luscious sugar; and others, as, for instance, the Corsican or Irish Moss, have a health-restoring bitter; and all, without exception, contain a concentrated and most nourishing mucilage, not a few of them saviours to the weak, worn, perishing lungs of presumptuous and ungrateful man. Where we now exhibit iodine, the English formerly used nothing but a confection of that same Corsican, or Irish, Moss.

- The third characteristic of that vegetation is its marvellous amorousness. We cannot doubt that if we pay the slightest attention to its strange hymeneal metamorphoses, here is the striving to be, beyond being, to be potent beyond power. We see it in the fire flies and the like small things, and we see it no less, if we will only look for it, in the sea weeds which, at the consecrated moment, seem to quit their merely vegetable life and leap into animality.

The utilisation of various seaweeds for their therapeutic and medicinal benefits over the centuries is a testament to their purported efficacy. Modern medicine, however, has usurped society's reliance on nature for healthcare remedies, and lung infections and other ailments today are treated with the appropriate anti-bacterials or anti-virals. Medicinal plants, including seaweeds, were depended upon to treat many ailments, particularly in coastal communities around the world. One could argue this to be a resource availability situation, rather than a result of actual health benefits, but today, science has validated many of the claims. As an example, in Ireland, a traditional treatment for chest and lung ailments used Irish moss boiled in water or milk, strained and drunk hot (Allen and Hatfield 2004). The alga was also used to treat kidney ailments and burns. These medicinal applications were so valued that a recipe for preparing a demulcent from Chondrus crispus 'for diseases of debility' was included in an early Materia Medica (Frazer 1864). The relaxing effects of the extracted carrageenans on mucous membranes provided relief in tuberculosis, whooping cough, pneumonia, quinsy and for various gastrointestinal complaints (Fig. 7).

A curious use of seaweed extract has been reported for emergency blood transfusions where the extract has been found to be more effective than sugared water or salt water because the dissolved algal polysaccharides are not broken down in the blood stream (Mathieson 1975).

Growing evidence regarding the influence of the human microbiome on health suggests this will be a new frontier in medical science (Cornish et al. 2019). Seaweeds will also play a role here, but only if appropriate clinical trials are undertaken to follow up on animal trials that have already demonstrated important prebiotic effects (Cherry et al. 2019).

\section{Seaweeds for combating infections and pandemics}

Infections from microorganisms and viruses constitute a condition of life for all human beings and most people suffer once, or many times, during the yearly cycle from infections, not least in their airways. The consequences of such infections range from the mild condition of a winter cold to critical cases of life-threatening pneumonia, common influenza and respiratory syndrome corona viral infections such as SARS-CoV and MERS-CoV, including the current pandemic COVID-19 (SARS-CoV-2).

Throughout history, humankind has witnessed global infections leading to massive casualties, virtually wiping out large fractions of the populations (Pereira and Critchley 2020). One of the health conditions that plays a critical role for surviving a serious infection in the lung and the airways is an intact and healthy immune system. A regular diet including judicious consumption of a variety of seaweeds can be a factor which bolsters the immune system (Brown et al. 2014), also 


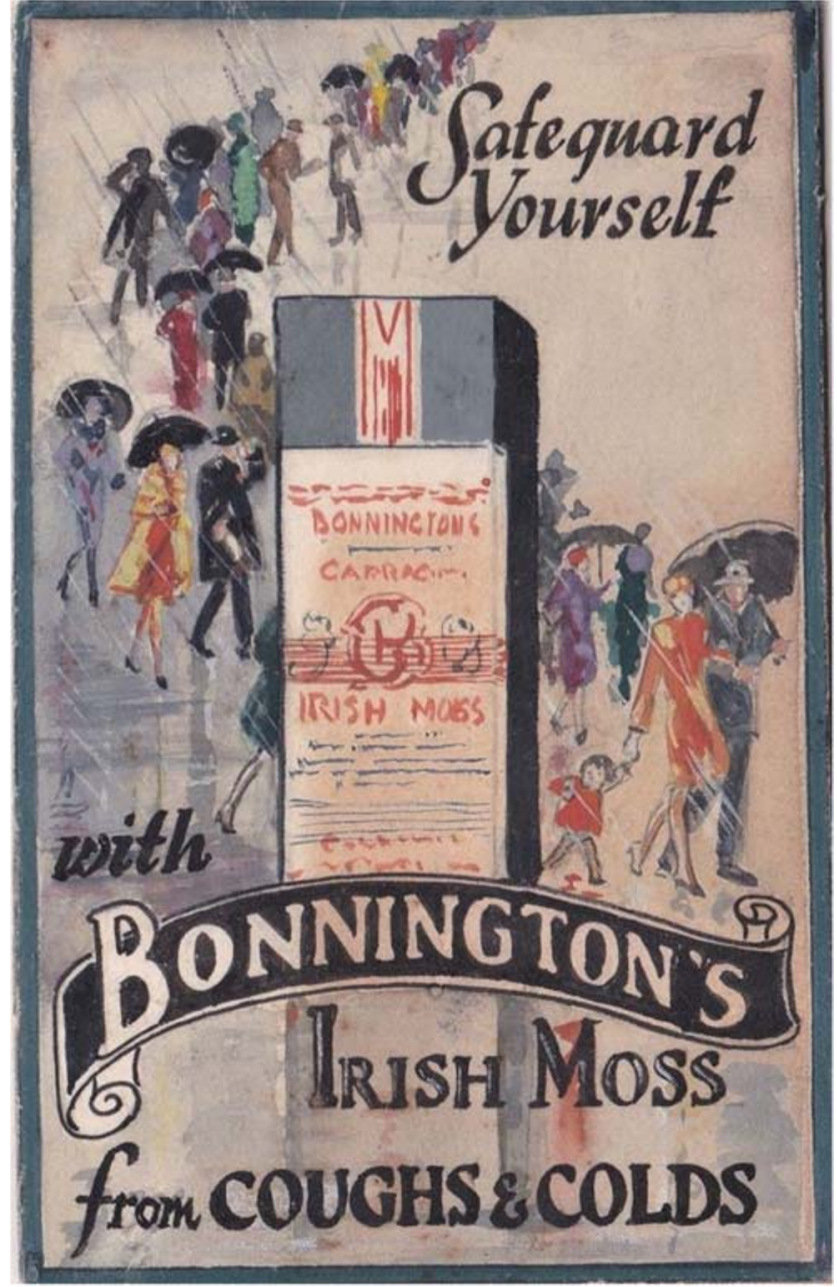

Fig. 7 British advertisement appraising Irish moss (Chondrus crispus) for curing infectious diseases like colds and coughs. (Public Domain) (https://bit.ly/2N7ZoqW)

by securing gut health and a diverse microbiome (Cornish et al. 2019; Jha et al. 2020).

In the case of the 2020-outbreak of the COVID-19 (SARS$\mathrm{CoV}-2$ ) pandemic and the following world economic crisis (Pereira and Critchley 2020), some food manufactures have observed a higher demand for products based on recipes involving seaweed extracts (Food Navigator 2020). This trend exposes the need for more fundamental and clinical research to establish a sound scientific basis for the claim that seaweeds can combat viral infections.

A number of in vitro and in vivo, as well as clinical, studies have established that certain chemical compounds in seaweeds have biological activity in terms of their antimicrobial and anti-viral efficacy, specifically certain peptides. In particular, research has demonstrated broad-spectrum in vitro activity and in vivo efficacy of the anti-viral protein griffthsin (isolated from the red seaweed Griffithsia sp.) against emerging viruses of the family Coronaviridae (O'Keefe et al. 2010). Other algal-derived polysaccharides (e.g. agar, alginate, fucoidan, carrageenan, laminarans, proteo-glycans, galactosyl glycerol and rhamnan sulphate) have in recent years showed some promising potential for combating viral infections and researchers have advocated that the pharmaceutical industry should turn their attention to explore this potential (Ahmadi et al. 2015).

\section{Seaweeds ameliorating changes in climate}

It is now recognized by most scientists and politicians that global climate changes are a consequence of anthropogenic activities. These changes involve global warming and more extreme weather conditions, which are accompanied by melting of the ice caps, ocean warming, rising of sea-levels, acidification of the oceans, flooding, droughts and forest fires (Sonali and Kumar 2020). One of the most important reasons for these effects is the dramatic rise in emission of greenhouse gases (GHGs), in particular methane and carbon dioxide. The atmosphere's concentration of carbon dioxide has increased by about $40 \%$ since the pre-industrial era. Both with respect to methane and carbon dioxide emissions, seaweeds may come to partial rescue but in very different ways.

Until recently, the contribution of coastal seaweeds and the vast populations of microalgae in the open oceans to the sequestration of global carbon was largely neglected, although already in 1981, Smith (1981) pointed out that marine macrophytes work as a carbon sink. The reason for not taking seaweeds into the calculation of the so-called Blue Carbon-accounting (Blue Economy) was predominantly that seaweeds, in contrast to seagrass-dominated ecosystems, do not deposit carbon near its own rocky habitats (Krause-Jensen and Duarte 2016). Recent work, which also described the sequestering of macroalgal carbon as the 'elephant in the Blue Carbon room', also pointed out that there was compelling evidence that carbon flux from seaweeds accumulated in deep-sea sediments (Krause-Jensen et al. 2018).

The estimated total global export of organic carbon to the ocean has been estimated as $2.4 \mathrm{Pg}$ carbon year ${ }^{-1}$, of which the autotrophic seaweeds alone contributed to $1.5 \mathrm{Pg}$ carbon year $^{-1}$, i.e. a very significant fraction (Krause-Jensen et al. 2018). Of this amount, about $0.173 \mathrm{Pg}^{\mathrm{P}}$ carbon year ${ }^{-1}$ (i.e. $11 \%$ ) from seaweeds are potentially sequestered in sediments and deep-sea beds. An outstanding challenge is to trace this flux from the coastal habitats into the deep sea and provide a detailed interpretation of its significance to the global carbon cycle. Although the issue is still somewhat controversial, researchers have also pointed to the importance and adaptation effects of seaweeds due to climate changes, including reduction of wave energy and water flow during storm-flooding, thereby promoting sedimentation, as well as reduction in ocean acidity (for references, see Krause-Jensen et al. 2018). 
Obviously, our understanding of the sequestration of carbon by wild resources of seaweed populations, or even enhanced biomass due to phyconomic/aquaculture activities, will not by themselves help to lower carbon dioxide emissions, but they are part of the solution to amelioration of the problems caused. Insightful management of natural resources, as well as increased cultivation of various seaweeds, will have positive effects, although an upper limit for the latter has been estimated at a modest $0.4 \%$ of the total seaweed-captured carbon at $0.173 \mathrm{Pg} \mathrm{year}^{-1}$ (Duarte et al. 2017; Laurens et al. 2020) (Fig. 8).

Other ways seaweeds may be used to reduce the footprint of carbon dioxide emissions include replacement strategies for terrestrial food production by seaweed biomass (to be dealt with below) or as a biofuel blend to extend fossil-derived reserves (Chen et al. 2015). It has been estimated that using seaweeds instead of fossil fuel for the production of bioethanol and methane reduces the emission of GHGs by $8 \%$, and even up to 54\%, respectively (Fry et al. 2012).

There appear to be two ways in which different seaweeds might help mitigate climate effects caused by ruminant GHG emissions. One is to find more sustainable protein sources so as to replace meat for human consumption (which we will return to later). The other is to reduce the total gas and methane emissions by manipulating the diet of cattle to include seaweeds (Machado et al. 2014; Roque et al. 2019). It is now clear that some seaweeds and their products do indeed lower the emission of methane from ruminant digestion (Kinley and Fredeen 2015). In particular, the red alga Asparagopsis taxiformis has shown promising effects. By replacing just $2 \%$ of the feed by its dried biomass, it was found that methane was reduced by $70 \%$ (Kinley and Vucko 2016) and by $99 \%$ with a $5 \%$ supplementation of grass feed supplemented with Asparagopsis (Machado et al. 2016). At the same time, those cattle ingesting seaweeds were healthier than those feeding on a traditional cattle diet. Hence, emissions of ruminant, enteric fermentation-induced GHG can be reduced significantly by adding various seaweeds to the feed (i.e. this

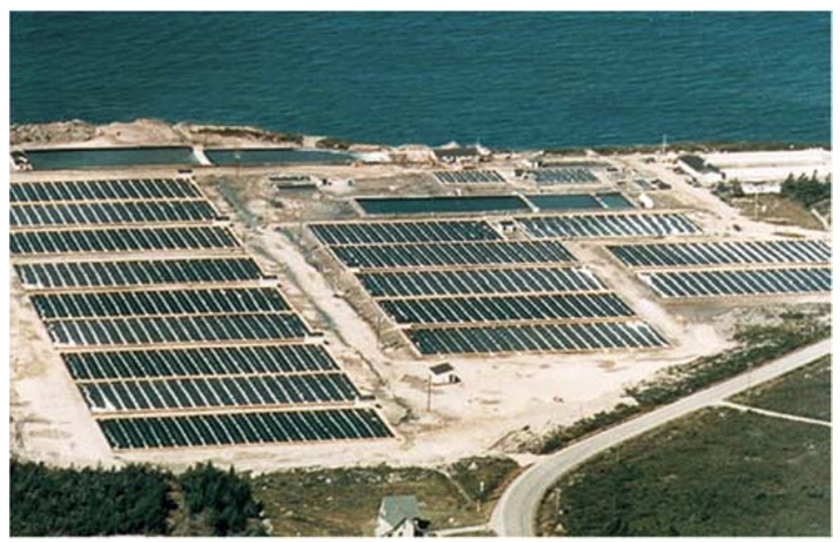

Fig. 8 On-land aquaculture of seaweeds (Chondrus crispus) at Acadian Seaplants, Nova Scotia, Canada property is not exclusive to A. taxiformis). Implementation of these promising results on a large scale is hampered by the limited access to A. taxiformis which would require establishment of extensive phyconomic operations. Clearly, further research into the effects of other more commonly available seaweeds is required.

\section{Seaweeds combating pollution}

A myriad of seaweeds has shown themselves to serve humankind during critical cases of contamination and pollution in the ocean environment. Two rather different examples provided here demonstrate how the phyconomic enhancement and increased production of selected seaweeds can help mitigate some of the detrimental impacts of human activities on ocean ecosystems.

The first example pertains to the unique capacity of seaweeds for binding metals to their polysaccharides, in particular heavy metals from wastewaters. It has been known for a long time, that in particular brown seaweeds have a capacity for binding metal ions (Bryan 1969). The ability of brown seaweeds to act as a biosorbent for clearing metals in both aqueous environments, as well as soil, is based on the chemical composition and ion-exchange capacity of compounds associated with the cell walls of brown seaweeds, i.e. alginates and fucoidans, with functional groups capable of binding metal ions. Planting of seaweeds in wastewater reservoirs has been implemented in areas of effluent remediation areas (Ortiz-Calderon et al. 2017; Michalak 2020a). Recently, Pennesi et al. (2019) illustrated how the rare metal indium could be recovered from e-waste (old electronic materials), much of which is exported to developing countries where workers (many of whom are children) burn circuit boards to recover precious and rare metals. This causes major health and pollution issues. Biomass of the brown seaweed Ascophyllum nodosum was found to help 'mine' in solution the metal indium which is required as an input to new electronics and especially screens (Pennesi et al. 2019).

Particularly since the 'oil crisis' of the 1970s, many authors have suggested that seaweeds could be further exploited as a sustainable source of 'feedstock' for biofuel production (Michalak 2020b, see also below). Related to the issue of removing unwanted toxic elements in seawater is that seaweed forests, present and those developed through inoculation of some form of engineered marine substrata, as in marine ranching (Ohno and Critchley 1993) also helps to clean up the ocean by capturing some of the fertilizer run-off from agricultural and urban areas (Fig. 9).

The second example pertains to using seaweeds in multitrophic aquaculture for the purpose of nutrient extraction from, e.g. fish farms. As mentioned in the introduction, super-unsaturated fatty acids are a limited resource on the 


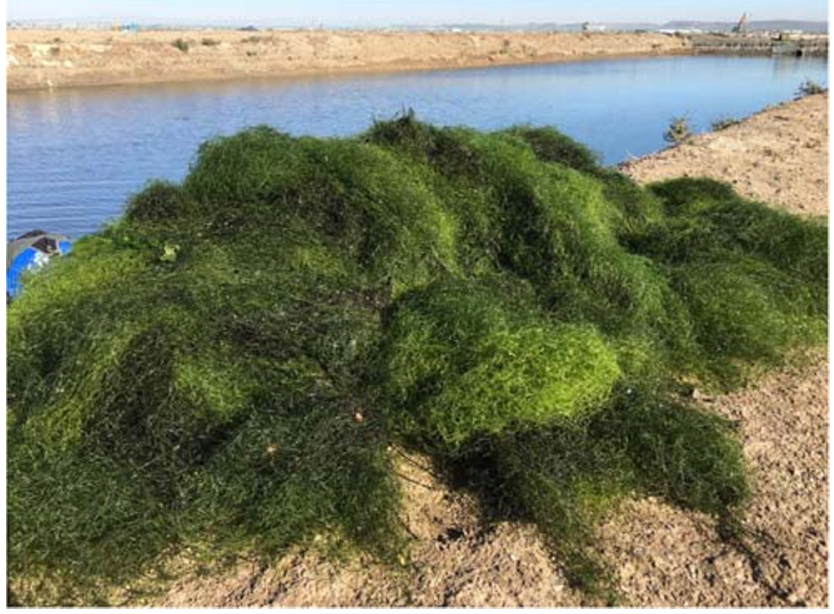

Fig. 9 The green seaweed Chaetomorpha linum sn used as a natural filter in some estuaries from Cádiz Bay, Spain. Courtesy of Juan José Vergara

planet, and due to the negative environmental effects of aquaculture (as currently practiced), it is increasingly problematic to increase the farming of fish. Since wild fish stocks are under pressure and fisheries are dwindling (FAO 2018a), a critical situation will arise for our access to nutritional superunsaturated fatty acids like omega-3 fatty acids. One possible solution to the problem of farming more fish is via so-called integrated multi-trophic aquaculture (IMTA). IMTA involves selected seaweeds (mostly kelps for a part of the season) in an ecosystem with fish and filter feeders such as shellfish (Chopin 2013; Correia et al. 2020), i.e. the uneaten feed and dissolved wastes of one trophic level (generally carnivorous fish) are regained and used as feed, fertilizers and energy for multiple species in lower trophic orders. Specifically, the seaweeds exploit the excess nitrogen and inorganic waste from the fish (at least for the parts of the year they are present) and molluscs can take advantage of the organic debris and uneaten fish feed.

\section{Seaweeds and the plastics crisis}

Modern societies without plastics are almost unimaginable and in particular after WW2, plastic products have been an omnipresent commodity in peoples' material life. From being considered a reusable resource, more that $90 \%$ of plastics are now single-use plastic that are designed to be used only once, in particular for packaging, and only a few percent of this plastic is being recycled. More than $10 \%$ of the solid waste from households are now plastics. As a consequence, 8.3 billion tonnes of massive plastic pollution have been piled up on the planet over the last 60 years (Geyer et al. 2017) and the mass is rapidly increasing. The poorly degradable plastic waste ends up in rivers, oceans and landfills where it will stay for hundreds of years. Microplastics are now considered as having a toxic effect on animals and the environment. We are facing a veritable plastic crisis that is endangering our environment and the ecology of the planet to an extent that plastics have been proposed as a geological indicator of the Anthropocene (Zalasiewicz et al. 2016).

Circular economy, regeneration and reuse of plastics is one way to mitigate the disaster. Development and use of bioplastics from non-petroleum biomaterials constitute another route involving biodegradable, inexpensive, and natural resources, and it is here that seaweeds may come in as part of the rescue plan (Rajendran et al. 2012; Phipps 2020). Bioplastics are typically produced using corn, vegetable oil and starch, but since these products are also human food, farming them for plastics will use valuable land, require fertilizers, fresh water and possibly contribute to a future food crisis. Using farmed seaweeds for bioplastics could mitigate some these problems.

Most bioplastics that are produced on a commercial scale are poly-lactic acid poly-hydroxyalkanoates, starch plastics, cellulose plastics and proteins plastics (Mekonnen et al. 2013) that are biodegradable. Bioplastics from seaweeds are based in particular on the polysaccharides agar, carrageenan and alginate, and seaweed waste from agar extraction has been proposed as a material filler (Zhanga et al. 2019) (Fig. 10). Often, the polysaccharides enter a bio-composite structure with other biodegradable polymers and the introduction of seaweed material has led to plastics that show improved mechanical and thermal performance, e.g. they are more resistant to microwave radiation and less brittle and durable (Rajendran et al. 2012; Madera-Santana et al. 2015), e.g. for use in the pharmaceutical industry (Gade et al. 2013).

A major use of plastics is film for packaging of foodstuff and drinks, and some results have been reported for obtaining seaweed-based infusion sachets and edible containers and films and that are transparent, stretchable and sealable and have basic properties as a film for food packaging (Siah et al. 2015; Khalil et al. 2017). Interestingly, plastic drinking straw rubbish is one of the largest contributors to plastic waste,

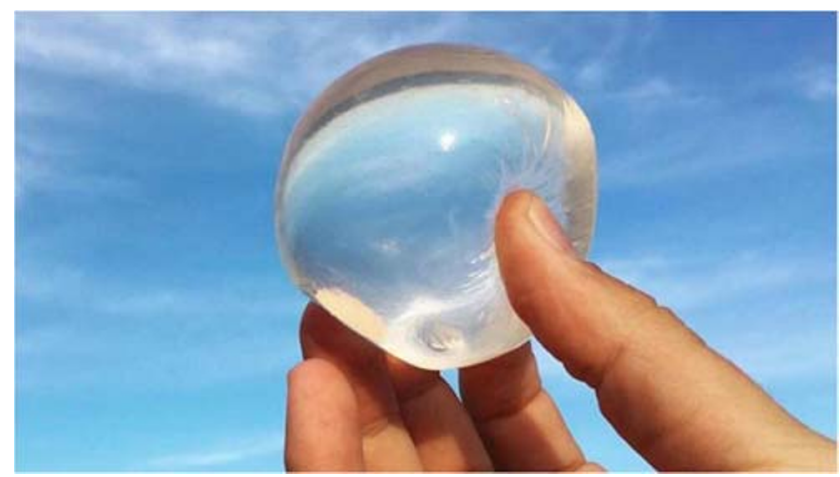

Fig. 10 An edible and biodegradable pouch made of seaweeds as a handy container for fresh water. https://shorturl.at/bjEJQ 
and a range of different seaweeds have been explored for manufacturing a bio-degradable straw (Ardiansyah et al. 2019).

Although some significant progress has been obtained over the last decade, the field of bioplastics from seaweeds is still in its infancy.

\section{Seaweeds for sustainable energy}

Access to sustainable energy sources is absolutely critical for all parts of the world now and for forming and sustaining our future. Fossil fuel for transportation and production of electricity is a limited resource and the combustion of fossil material is an over-arching factor behind climate changes and global pollution. Alternative, sustainable and renewable energy production is in great demand. Therefore, seaweeds have been on the radar of the energy sector, where they may be a means of meeting growing global demand and of decreasing the carbon footprint that is attributable to anthropogenic activities in particular with respect to emission of greenhouse gases (Fig. 11).

With a view to solving some of the major problems confronting the transportation sector by finding a replacement for oil and gasoline, significant research activities have been mounted to use both micro- and macroalgae for the production of bioethanol (Kraan 2016; Jiang et al. 2016; Kaur et al. 2018; Gegg and Wells 2019; Gao et al. 2020). However, even after this research, much of this work is still on an experimental scale and the further investments in research and development are highly dependent on the current market price for fossil fuels. Leading companies in the aviation industry are currently experimenting with how to produce biomass from microalgae for third-generation alternative biofuels to power passenger jet planes, and worldwide, a major research effort is being carried out to develop microalgal-based processes for production of

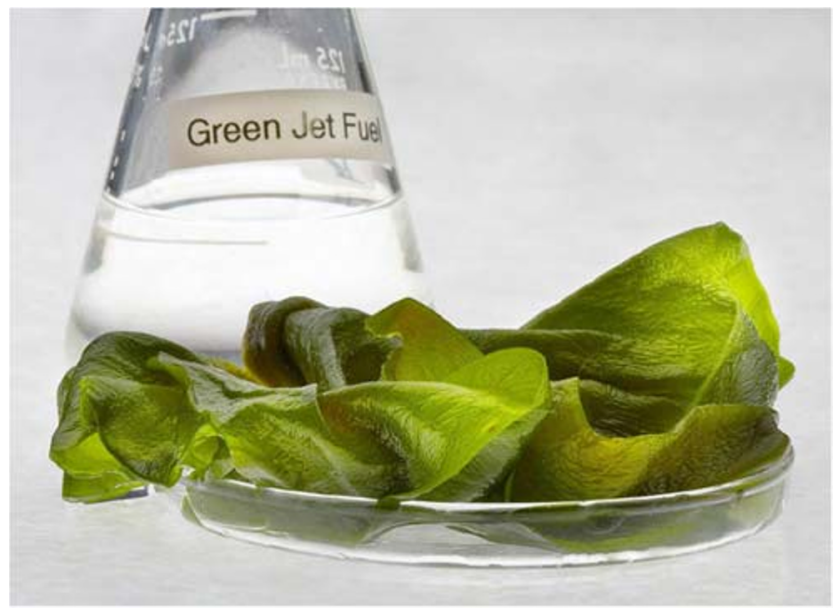

Fig. 11 Seaweeds for production of biofuels. (CC BY-SA 3.0) (https:// bit.ly/2ANu6mS) renewable energy (Jacob-Lopes et al. 2019). It is noteworthy that, unlike many other biofuels from land-based plants or edible seaweeds, those based on microalgae and selected non-food-use seaweeds (i.e. some of the red seaweeds of Gracilaria spp. or Eucheuma spp.) have relatively low-value colloids (i.e., non-agar and carrageenan respectively) and might be an economically viable biomass for mass cultivation as a feedstock for energy) would not displace food crops nor provide competition for freshwater resources.

At present, farming seaweeds for energy production remains non-economically viable, and it would possibly need to be coupled to prior use of the same seaweeds (as waste) that first are used for other purposes, in a MUZE (multiple-use zero effluent) or biorefinery approach such as pollution abatement (Michalak 2020b). In addition to access to sufficient biomass (many millions of metric tonnes in continuous production) of many types of seaweeds for industrial, large-scale biofuel production, there are major scientific and technological challenges involved with design and development of enzyme systems that effectively can break down seaweed polysaccharides into fermentable sugars (Maneein et al. 2018; Ramachandra and Hebbale 2020).

\section{Seaweeds for sustainable eating}

It may seem strange that although there are many thousands of different seaweed species in their total diversity, as with land plants, the selection of seaweeds which are commonly eaten is perhaps less than 200 in total, i.e. conservatively less than $2 \%$. This may change as the focus is shifting towards a more sustainable eating behaviour (Mouritsen and Schmidt 2020).

In the report Food in the Anthropocene, the EAT-Lancet Commission 2019 on Healthy Diets from Sustainable Food Systems presented a solution for a daily diet that can meet the requirements for feeding a global population of 10 billion in 2050 with a healthy and nutritious diet from sustainable food systems (Willett et al. 2019). The diet implies that humans must each eat $500 \mathrm{~g}$ of greens daily, consisting mainly of vegetables, fruit, whole grain, legumes, nuts and unsaturated fats, but only moderate or small amounts of fish and poultry with no, or very little, red meat, processed meat, added sugars, refined cereals and starchy vegetables. Note that likely out of ignorance, marine-produced vegetation, seaweeds and microalgae were missing from this listing of largely terrestrial-based, farmed species. With this recommendation, the Commission argued that it should be possible to meet the United Nations Sustainable Development Goals (United Nations 2019). The Commission pointed out that their solution was indeed fragile, and even a small increase in the consumption of red meat, or dairy products, may catastrophically tip the balance required. 
The report is based on a grim background noting that the global food systems in the Anthropocene are the main reason for the changing ecosystems of the Earth, including changes in climate. Agriculture occupies $40 \%$ of the land (Foley et al. 2005) and is responsible for $30 \%$ of all GHG emissions (Vermeulen et al. 2012), and $70 \%$ of the freshwater usage (Steffen et al. 2015). Fisheries have fully exploited $60 \%$ of wild stocks, while over-fishing another $30 \%$; as a result, the global catch has diminished in recent decades. The aquaculture of fish and shellfish cannot easily be expanded due to pollution and lack of sustainability in most fish farms. The true cost of this type of food production system has been a significant loss in biodiversity and serious damage to whole ecosystems, as well as the emission of excess nutrients and GHGs. The global cycles of carbon, phosphorus and nitrogen have been disturbed, and food waste from production to consumption is skyrocketing. It is clear that the current global food systems are neither sustainable, nor healthy (Searchinger et al. 2019; Willett et al. 2019) (Fig. 12).

Hence, there is no way around that we have to eat more greenly produced greens (GPGs), i.e. predominantly plantbased foodstuff. Eating more GPGs, e.g. vegetables, is however in itself not a straightforward undertaking. There are two fundamental reasons why a green diet may not be to our liking. One has to do with the biology of the plants and the other is deeply rooted in human evolution (Schmidt and Mouritsen 2020). Green plants are, by nature, generally bitter and lack the sweet and umami tastes that humans, over evolutionary time scales, have become primed to crave (Mouritsen and Styrbæk 2014).

Seaweeds may again come in here as a rescue agent, and although of different colours (i.e. red, brown and green), they may well quality as GPGs. The EAT Lancet Commission report (Searchinger et al. 2019; Willett et al. 2019) neglected to mention seaweeds as being part of the solution to eating greener although a recent High Level Panel for a Sustainable Ocean Economy highlighted that seaweeds were the fastest

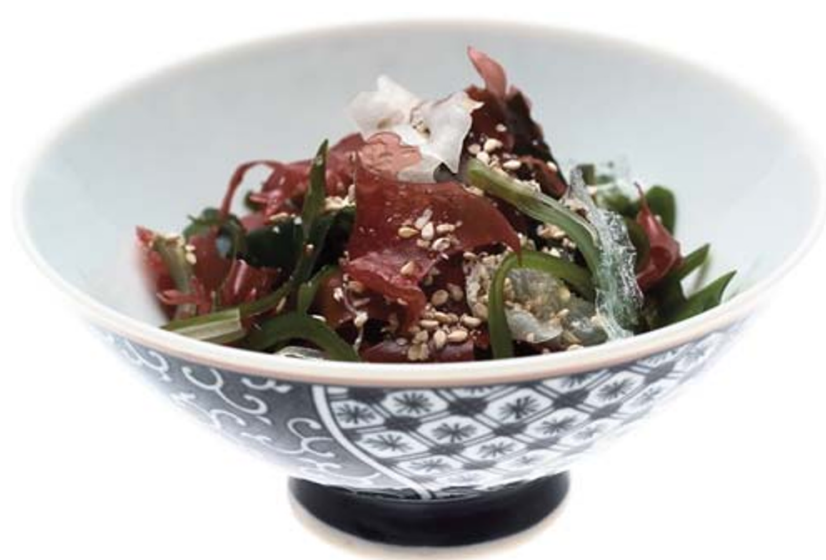

Fig. 12 Seaweed salad composed of mixed species. Courtesy of Jonas Drotner Mouritsen growing aquaculture (phyconomic) sector with an un-tapped potential for food production (Costello et al. 2019). We would propose that multiple seaweeds have to be considered as part of green, sustainable eating in the future and point out that seaweeds are probably some of the most carbon-neutral types of foodstuff.

There is a considerable literature base about edible seaweeds (Mouritsen 2013; Pereira 2016; Pérez-Lloréns et al. 2018; Ferrara 2020). Global production is around 30 million tonnes of which $97 \%$ derives from aquaculture (Buschmann et al. 2017; FAO 2018b). About half of the production is used as human food. Seaweeds are high in both macro- and micronutrients, minerals and vitamins, as well as superunsaturated omega-3 fatty acids, in particular EPA (Mouritsen 2013; Shannon and Abu-Ghannam 2019). In relation to economic sustainability, a recent calculation showed that the economic value of marine vegetation is almost 20 times higher than that of terrestrial forests per hectare (Pérez-Lloréns et al. 2018). Although globally there is a large production of seaweeds for food, it has been calculated that just replacing $1 \%$ of the global human diet with seaweed would require 73 times the current production (Forster and Radulovich 2015). Currently, there are severe phyconomic, economic, technological and regulatory challenges that must be addressed in order to make such an expansion in seaweed production possible (Buschmann et al. 2017).

However, we would like to emphasize that small amounts of selected seaweeds can add to the flavour and texture profile of plant-based foods making them more delectable (Mouritsen and Schmidt 2020). In particular, some seaweeds contribute a substantial umami taste (Mouritsen 2017; Mouritsen et al. 2019a), e.g. in the form of an aqueous extract, dashi, most prominently known from the properties of Japanese konbu (Saccharina japonica). Whereas most other brown seaweeds do not contribute much umami (Mouritsen et al. 2019a), the red seaweed dulse ( $P$. palmata) is an excellent source of free glutamate and hence the umami taste (Mouritsen et al. 2013). 'Umamification' of vegetables may be one route to eating more greens, either by using dashi or seaweeds as whole foods and as a condiment to green dishes. Seaweeds and seaweed gastronomy, recently coined as phycogastronomy (PérezLloréns et al. 2018; Mouritsen et al. 2018, 2019b), should be counted on to provide for more sustainable eating based on the phyconomic principles and prospects of sustainable seaweed aquaculture (Hurtado et al. 2019; Barbier et al. 2020).

\section{Closing remarks}

Considering the diversity and global proliferation of the ancient and heterogeneous group of seaweeds covering three different phyla, it may not be surprising that these remarkable organisms with their many spectacular properties have been 
linked to the evolution and livelihood of humankind during hundreds of thousands of years. Still, most people are oblivious of their services to us, both during evolution and not least in historical times as well as present days. In this review, we have brought seaweeds into the limelight with a focus on how they have come to rescue during times of crisis, time and time again, and may well come to play an important role at the various crises we are facing today and in the future (Doumeizel and Aass 2020).

Seaweeds may be a game changer in future food, feed, fuel, carbon capture and storage, medicine, disease prevention and health, to name a few areas. Scientific research, industrial innovation, and new operations can, together with governments and multilateral organisations, open the path for new industries to deliver on the 17 UN Sustainable Development Goals, also including ecosystem support, poverty alleviation, ocean restoration and coastal community resilience (United Nations 2019). The time is ripe to learn from history and unlock new seaweed value chains as drivers of the Sustainable Development Goals by investing in scientific research and reap the benefits of the results by exploring novel applications, developing new technologies and globally distributing the positive goods and services to be derived from seaweeds for all humankind.

Funding The work by OGM is supported by the Nordea Foundation via a centre grant to the research and communication centre Taste for Life.

\section{Compliance with ethical standards}

Conflict of interest The authors declare that they have no conflict of interest.

\section{References}

Ahmadi A, Moghadamtousi SF, Abubakar S, Zandi K (2015) Antiviral potential of algae polysaccharides isolated from marine sources: a review. BioMed Res Intl 2015:825203

Allen DE, Hatfield G (2004) Medicinal plants in folk tradition - an ethnobotany of Britain and Ireland. Crit Rev Food Sci Nutr 48:905-912

Ardiansyah MF, Alamsyah MS, Aulia F, Awinda K, Sanjaya L (2019) Seruput (seaweed straw) as a solution to reduce plastics waste for realize SDG's in Indonesia. Proc 7th Asian Acad Soc Int Conf 2019, pp 121-124

Aslan LOM, Supendy R, Taridala SAA, Hafid H, Sifatu WO, Sailan Z, Niampe L (2018) Income of seaweed farming households: a case study from Lemo of Indonesia. Earth Environ Sci 175:012221

Attjioui M, Ryan S, Ristic A, Higgins T, Goni O, Gibney E, Tierney J, O'Connell S (2020) Kinetics and mechanism of $\alpha$-glucosidase inhibition by edible brown algae in the management of type 2 diabetes. Proc Nutr Soc 79

Auckland Star (1942) Seaweed product. Use in wartime. Needed in Hospitals. Auckland Star, 16 January, p. 2 http://www.TeAra.govt. nz/en/document/4604/the-right-seaweed (accessed 10 Sept 2020)

Barbier M, Araújo R, Rebours C, Jacquemin B, Holdt SL, Charrier B (2020) Development and objectives of the PHYCOMORPH
European Guidelines for the Sustainable Aquaculture of Seaweeds (PEGASUS). Bot Mar 63:5-16

Bay-Larsen I, Hovelsrud G, Rødven R, Robledo D (2014) Seaweeds: an opportunity for wealth and sustainable livelihood for coastal communities. J Appl Ecol 26:1939-1951

Bermanoa G, Stoyanovaa T, Franck Hennequart F, Wainwright CL (2020) Seaweed-derived bioactives as potential energy regulators in obesity and type 2 diabetes. Adv Pharmacol 87:205-256

Blaine G (1946) The use of plastics in surgery. Lancet 251:525-528

Braverman ER, Blum K, Loeffke B, Baker R, Kreuk F, Yang SP, Hurley JR (2014) Managing terrorism or accidental nuclear errors, preparing for iodine-131 emergencies: a comprehensive review. Int J Environ Res Public Health 11:4158-4200

Breinholst W (1963) LITEX 1938-1963. LITEX Industry, Copenhagen

Brown EM, Allsopp PJ, Magee P (2014) Seaweed and human health. Nutr Rev 72:205-216

Bryan GW (1969) The absorption of zinc and other metals by the brown seaweed Laminaria digitata. J Mar Biol Assoc UK 49:225-243

Buschmann AH, Camus C, Infante J, Neori A, Israel A, HernándezGonzález MC, Pereda SV, Gomez-Pinchetti JL, Golberg A, Tadmor-Shalev N, Critchley AT (2017) Seaweed production: overview of the global state of exploitation, farming and emerging research activity. Eur J Phycol 52:391-406

Cardoso SM, Pereira OR, Seca AML, Pinto DCGA, Silva AMS (2015) Seaweeds as preventive agents for cardiovascular diseases: from nutrients to functional foods. Mar Drugs 13:6838-6865

Chapman VJ (1950) Seaweeds and their uses. Methuen \& Co. Ltd., London

Chapman RL (2013) Algae: the world's most important "plants"—an introduction. Mitig Adapt Strat Global Change 18:5-12

Chen H, Zhou D, Luo G, Zhang S, Chen J (2015) Macroalgae for biofuels production: progress and perspectives. Renew Sust Energ Rev 47: $427-437$

Cherry P, Yadav S, Strain CR, Allsopp PJ, Sorley EM, Ross RP, Stanton C (2019) Prebiotics from seaweeds: an ocean of opportunity? Mar Drugs 17:327

Chopin T (2013) Aquaculture, integrated multi-trophic (IMTA). In: Meyers MA (ed) Marine fisheries enhancement: coming of age in the new millennium. Springer, Dordrecht, pp 542-564

Collins KG, Fitzgerald GF, Stanton C, Ross RP (2016) Looking beyond the terrestrial: the potential of seaweed derived bioactives to treat non-communicable diseases. Mar Drugs 14:60

Cornish ML, Critchley AT, Mouritsen OG (2015) A role for dietary macroalgae in the amelioration of certain risk factors associated with cardiovascular disease. Phycologia 54:649-666

Cornish ML, Critchley AT, Mouritsen OG (2017) Consumption of seaweeds and the human brain. J Appl Phycol 29:2377-2398

Cornish ML, Mouritsen OG, Critchley AT (2019) A mini-review on the microbial continuum: consideration of a link between judicious consumption of a varied diet of macroalgae and human health and nutrition. J Oceanol Limnol 37:790-805

Correia M, Azevedo IC, Peres H, Magalhães R, Oliva-Teles A, Almeida CMR, Guimarães L (2020) Integrated multi-trophic aquaculture: a laboratory and hands-on experimental activity to promote environmental sustainability awareness and value of aquaculture products. Front Mar Sci 7:156

Costello C, Cao L, Gelcich S et al (2019) The future of food from the sea. World Resources Institute. Available online at, Washington, DC. https://oceanpanel.org/sites/default/files/2019-11/19_HLP_ BP1\%20Paper. Accessed 29 Sept 2020

Craigie JS (2011) Seaweed extract stimuli in plant science and agriculture. J Appl Phycol 23:371-393

Crawford MA, Marsh D (1989) The driving force. Food, evolution, and the future. Harper \& Row, London 
Cunnane S, Stewart K, Tattersall I (2014) The role of freshwater and marine resources in the evolution of the human diet, brain and behaviour. J Hum Evol 77:1-216

Déléris P, Nazih H, Bard JM (2016) Seaweeds in human health. In: Fleurence J, Levine A (eds) Seaweed in health and disease prevention. Academic Press, London, pp 319-368

Dillehay TD, Ramírez C, Pino M, Collins MB, Rossen J, Pino-Navarro JD (2008) Monte Verde: seaweed, food, medicine and the peopling of South America. Science 320:781-786

Domínguez H (ed) (2013) Functional ingredients from algae for foods and nutraceuticals. Woodhead Publ, Oxford

Doumeizel V, Aass K, eds (2020) Seaweed revolution. A manifesto for a sustainable future. Lloyd's Register Foundation, Sustainable Ocean Business Action Platform. 16 http://www.seaweedmanifesto.com. Seen 25 Jun 2020

Duarte CM, Wu J, Xiao X, Bruhn A, Krause-Jensen D (2017) Can seaweed farming play a role in climate change mitigation and adaptation? Front Mar Sci 4:100

Erlandson JM, Graham MH, Bourque BJ, Corbett D, Estes JA, Steneck RS (2007) The kelp highway hypothesis: marine ecology, the coastal migration theory, and the peopling of the Americas. J Isl Coast Archaeol 2:161-174

Falkenberg M, Nakano E, Zambotti-Villela L, Zatelli GA, Philippus AC, Imamura KB, Velasquez AMA, Freitas RP, de Freitas TL, Colepicolo P, Graminha MAS (2019) Bioactive compounds against neglected diseases isolated from macroalgae: a review. J Appl Phycol 31:797-823

FAO (2018a) The State of World Fisheries and Aquaculture 2018 Meeting the sustainable 246 development goals. FAO, Rome

FAO (2018b) The global status of seaweed production, trade and utilization. Globefish Research Programme. Vol. 124. FAO, Rome

Ferrara L (2020) Seaweeds: a food for our future. J Food Chem Nanotechnol 6:56-64

Fleurence J, Levine A (eds) (2016) Seaweed in health and disease prevention. Academic Press, London

Foley JA, Defries R, Asner GP (2005) Global consequences of land use. Science 309:570-574

Food Navigator (2020) https://www.foodnavigator.com/Article/2020/05/ 15/Seaweed-supplier-Algaia-enjoys-sales-boom-as-coronavirusaccelerates-shift-to-traceable-food-solutions. Seen 25 Jun 252020

Forsberg V, Vestling V (2018) The livelihoods of female seaweed farmers. A study about women's experiences of old and new techniques of seaweed farming on Zanzibar, Tanzania. Jönköping University, School of Education and Communication

Forster J, Radulovich R (2015) Seaweed and food security 2015. In: Tiwari BK, Troy DJ (eds) Seaweed sustainability. Elsevier, Amsterdam, pp 289-313

Frazer W (1864) Elements of Materia Medica. John Churchill and Sons, Edinburg

Freeborn A (2014) How a seaweed scientist helped win the war. https:// www.nhm.ac.uk/natureplus/blogs/behind-the-scenes/2014/03/26/ how-a-seaweed-scientist-helped-win-the-war.html. Seen 25 Jun 25 2020

Freile-Pelegrín Y, Tasdemir D (2019) Seaweeds to the rescue of forgotten diseases: a review. Bot Mar 62:211-226

Fry JM, Joyce PJ, Aumonier S (2012) Carbon footprint of seaweed as a biofuel. Prepared by Environmental Resources Management Limited (ERM) for the Crown Estate, London, p 64

Gade R, Tulasi MS, Bhai VA (2013) Seaweeds: a novel biomaterial. Int J Pharm Pharmaceut Sci 5:40-44

Gallagher T (1982) Paddy's lament. Ireland 1846-1847. Prelude to Hatred. Harcourt Brace \& Co, London

Gao G, Burgess JG, Wu M, Wang S, Gao K (2020) Using macroalgae as biofuel: current opportunities and challenges. Bot Mar 63:355-370
Gegg P, Wells V (2019) The development of seaweed-derived fuels in the UK: an analysis of stakeholder issues and public perceptions. Energy Policy 133:110924

Geyer R, Jambeck JR, Law KL (2017) Production, use, and fate of all plastics ever made. Sci Adv 3:e1700782

Guiry MD, Morrison L (2013) The sustainable harvesting of Ascophyllum nodosum (Fucaceae, Phaeophyceae) in Ireland, with notes on the collection and use of some other brown algae. J Appl Phycol 25:1823-1830

Guo F, Huang C, Cui Y, Haruki Moma H, Niu K, Nagatomi R (2019) Dietary seaweed intake and depressive symptoms in Japanese adults: a prospective cohort study. Nutr J 18:58

Hannan MA, Dash R, Haque MN, Mohibbullah M, Sohag AAM, Rahman MA, Uddin MJ, Alam M, Moon IS (2020) Neuroprotective potentials of marine algae and their bioactive metabolites: pharmacological insights and therapeutic advances. Mar Drugs. https://doi.org/10.20944/preprints202005.0342.v1

Harper D (2014) Kelp burning in the glens of Antrim. https:// antrimhistory.net/kelp-burning-in-the-glens-of-antrim-by-douglasharper/. Seen 25 Jun 252020

Holdt SL, Kraan S (2011) Bioactive compounds in seaweed; functional food applications and legislation. J Appl Phycol 23:543-597

Hurtado AQ, Neish IC, Critchley AT (2019) Phyconomy: the extensive cultivation of seaweeds, their sustainability and economic value, with particular reference to important lessons to be learned and transferred from the practice of eucheumatoid farming. Phycologia $58: 472-483$

Husni A (2018) Therapeutic potential of seaweed polysaccharides for diabetes mellitus. In: Maiti S (ed) Seaweed Biomaterials. IntechOpen, Riejeka, pp 27-45

Jacob-Lopes E, Zepka LQ, Queiroz MI (eds) (2019) Energy from microalgae. Springer, Berlin

Jha AK, Mathew S, Ravishankar CN (2020) Can sulphated polysaccharides from seaweed provide prophylactic and/or therapeutic solution to COVID-19 pandemic? Curr Sci 119:171-172

Jiang J, Shi S (2018) Seaweeds and cancer prevention. In: Qin Y (ed) Bioactive seaweeds for food applications. Natural Ingredients for Healthy Diets. Academic Press, New York, pp 269-290

Jiang R, Ingle KN, Golberg A (2016) Macroalgae (seaweed) for liquid transportation biofuel production: what is next? Algal Res 14:48-57

Kalumanga VE (2018) How seaweed farming improves the livelihoods of women's in the east coastal area of Zanzibar ArchipelagoTanzania. Int J Creative Res Thoughts IJPUB1802111:667-676

Kaur M, Kumar M, Sachdeva S, Puri SK (2018) Aquatic weeds as the next generation feedstock for sustainable bioenergy production. Biores Technol 251:390-402

Khalil HPSA, Saurabh CK, Tye YY, Lai TK, Easa AM, Rosamah E, Fazita MRN, Syakir MI, Adnan AS, Fizree HM, Aprilia NAS, Banerjee A (2017) Seaweed based sustainable films and composites for food and pharmaceutical applications: a review. Renew Sust Energy Rev 77:353-362

Khalilieh HS, Boulos A (2006) A glimpse of the uses of seaweeds in Islamic science and daily life during the classical period. Arab Sci Philos 16:91-101

Kim SK (ed) (2012) Handbook of Marine Macroalgae. Biotechnology and Applied Phycology. Wiley-Blackwell, Oxford

Kinley RD, Fredeen AH (2015) In vitro evaluation of feeding North Atlantic stormtoss seaweeds on ruminal digestion. J Appl Phycol 27:2387-2393

Kinley RD, Vucko MJ (2016) The red macroalgae Asparagopsis taxiformis is a potent natural antimethanogenic that reduces methane production during in vitro fermentation with rumen fluid. Animal Prod Sci 56:282

Kraan S (2016) Seaweed and alcohol: biofuel or booze? In: Fleurence J, Levine A (eds) Seaweed in health and disease prevention. Academic Press, London, pp 169-184 
Krause-Jensen D, Duarte CM (2016) Substantial role of macroalgae in marine carbon sequestration. Nature Geosci 9:737-742

Krause-Jensen D, Lavery P, Serrano O, Marba N, Masque P (2018) Sequestration of macroalgal carbon: the elephant in the Blue Carbon room. Biol Lett 14:20180236

Kreig MB (1966) Green medicine. Bantham Books, New York

Kristjánsson L (1980) íslenzkir Sjávarhættir I. Bókaútgáfa Menningarsjóđs, Reykjavík

Kunjuraman V, Hossin A, Hussin R (2019) Women in Malaysian seaweed industry: motivation and impacts. Kajian Malaysia 37:49-74

Laurens LML, Lane M, Nelson RS (2020) Sustainable seaweed biotechnology solutions for carbon capture, composition, and deconstruction. Trends Biotech. https://doi.org/10.1016/j.tibtech.2020.03.015

Long D (2014) Bizarre Scotland. Constable, London

Machado L, Magnusson M, Paul NA, de Nys R, Tomkins N (2014) Effects of marine and freshwater macroalgae on in-vitro total gas and methane production. PLoS One 9:e85289

Machado L, Magnusson M, Paul NA, Kinley R, de Nys R, Tomkins N (2016) Dose-response effects of Asparagopsis taxiformis and Oedogonium sp. on in-vitro fermentation and methane production. J Appl Phycol 28:1443-1452

Madera-Santana TJ, Freile-Pelegrin Y, Encinas JC, Rios-Soberanis CR, Quintana-Owen P (2015) Biocomposites based on poly(lactic acid) and seaweed wastes from agar extraction: Evaluation of physicochemical properties. J Appl Polym Sci 2015:42420

Mamvar F, Tahir PM, Mohamed R, Mahdavi M (2013) Biomedical properties of edible seaweed in cancer therapy and chemoprevention trials: a review. Nat Prod Commun 8:1811-1820

Maneein S, Milledge JJ, Nielsen BV, Harvey PJ (2018) A review of seaweed pre-treatment methods for enhanced biofuel production by anaerobic digestion or fermentation. Fermentation $4: 100$

Mathieson AC (1975) Seaweed aquaculture. Mar Fish Rev 37:2-14

Mathieu S, Touvrey-Loiodice M, Poulet L, Drouillard S, Vincentelli R, Henrissat B, Skjåk-Bræk G, Helbert W (2018) Ancient acquisition of "alginate utilization loci" by human gut microbiota. Sci Rep 8: 8075

Mazalovska M, Kouokam JC (2018) Lectins as promising therapeutics for the prevention and treatment of HIV and other potential coinfections. BioMed Res Intl 2018:3750646

McCall AA, Cummings CF, Bhave G, Vanacorev R, Page-McCaw A, Hudson BG (2014) Bromine is an essential trace element for assembly of collagen IV scaffolds in tissue development and architecture. Cell 157:1380-1392

Mekonnen T, Mussone P, Khalil H, Bressler D (2013) Progress in biobased plastics and plasticizing modifications. J Mater Chem A 1: 13379-13398

Michalak I (2020a) The application of seaweeds in environmental biotechnology. Adv Bot Res 95:85-111

Michalak I (2020b) Experimental processing of seaweeds for biofuels. Wiley Interdiscip Rev Energy Environ 7:e288

Michelet J (2013) The Sea (La Mer) https://www.gutenberg.org/files/ 42845/42845-h/42845-h.htm. Accessed 29 Sept 2020.

Milesi O (2018) Latin America backslides in struggle to reach zero hunger goal. https://reliefweb.int/report/world/latin-america-backslidesstruggle-reach-zero-hunger-goal. Accessed 29 Sept 2020.

Mouritsen OG (2013) Seaweeds. Edible, available \& sustainable. Chicago University Press, Chicago

Mouritsen OG (2017) Those tasty weeds. J Appl Phycol 29:2159-2164

Mouritsen OG, Schmidt CV (2020) A role for macroalgae and cephalopods in sustainable eating. Front Psychol 11:1402

Mouritsen OG, Styrbæk K (2014) Umami: unlocking the secrets behind the fifth taste. Columbia University Press, New York

Mouritsen OG, Dawczynski C, Duelund L, Jahreis G, Vetter W, Schroder M (2013) On the human consumption of the red seaweed dulse (Palmaria palmata (L.) Weber \& Mohr). J Appl Phycol 25:17771791
Mouritsen OG, Rhatigan P, Pérez-Lloréns JL (2018) World cuisine of seaweeds: science meets gastronomy. Int J Gastron Food Sci 14:5565

Mouritsen OG, Duelund L, Petersen MA, Hartmann AL, Frøst MB (2019a) Umami taste, free amino acid composition, and volatile compounds of brown seaweeds. J Appl Phycol 31:1213-1238

Mouritsen OG, Rhatigan P, Pérez-Lloréns JL (2019b) The rise of seaweed gastronomy: phycogastronomy. Bot Mar 62:195-209

Msuya F, Hurtado AQ (2017) The role of women in seaweed aquaculture in the Western Indian Ocean and South-East Asia. Eur J Phycol 52: 482-494

Murai U, Yamagishi K, Sata M, Kokubo Y, Saito I, Yatsuya H, Ishihara J, Inoue M, Sawada N, Iso H, Tsugane S, JPHC Study Group (2019) Seaweed intake and risk of cardiovascular disease: the Japan Public Health Center-based Prospective (JPHC) Study. Amer J Clin Nutr 110:1449-1455

Neushul P (1989) Seaweed for war: California's World War I kelp industry. Tech Cult 30:561-583

O'Connor K (2017) Seaweed: a global history. Reaction Books, London

O'Keefe BR, Giomarelli B, Barnard DL, Shenoy SR, Chan PKS, McMahon JB, Palmer KE, Barnett BW, Meyerholz DK, Wohlford-Lenane CL, McCray PB Jr (2010) Broad-spectrum in vitro activity and in vivo efficacy of the antiviral protein griffthsin against emerging viruses of the family Coronaviridae. J Virol 84: 2511-2521

Ohno M, Critchley AT (eds) (1993) Seaweed cultivation and marine ranching. Kanagawa International Fisheries Training Centre, Japan International Cooperation Agency, Yokosuka, p 151

Ortiz-Calderon C, Silva HC, Vásquez DB (2017) Metal removal by seaweed biomass. In: Tumuluru JS (ed) Biomass volume estimation and valorization for energy. IntechOpen, London, pp 361-380

Ott HJ (2018) Climate change eroding women's status in Zanzibar. https://pulitzercenter.org/reporting/climate-change-erodingwomens-status-zanzibar. Seen Jun 25, 2020

Peñalver P, Lorenzo JM, Ros G, Amarowicz R, Pateiro M, Nieto G (2020) Seaweeds as a functional ingredient for a healthy diet. Mar Drugs 18:301

Pennesi C, Amato A, Occhialini S, Critchley AT, Totti C, Giorgini E, Conti C, Beolchini F (2019) Adsorption of indium by waste biomass of brown alga Ascophyllum nodosum. Sci Rep 9:16763

Pereira L (2016) Edible seaweeds of the world. CRC Press, Boca Raton

Pereira L, Critchley AT (2020) The COVID 19 novel coronavirus pandemic 2020: seaweeds to the rescue? Why does substantial, supporting research about the antiviral properties of seaweed polysaccharides seem to go unrecognized by the pharmaceutical community in these desperate times? J Appl Phycol 32:1875-1877

Pérez-Lloréns JL, Hernández I, Vergara JJ, Brun FG, León A (2018) Those curious and delicious seaweeds. A fascinating voyage from Biology to Gastronomy. Editorial UCA, Cádiz

Pérez-Lloréns JL, Mouritsen OG, Rhatigan P, Cornish ML, Critchley AT (2020) Seaweeds in mythology, folklore, poetry, and life. J Appl Phycol. https://doi.org/10.1007/s10811-020-02133-0

Periyasamy C, Anantharaman P, Balasubramanian T (2014) Social upliftment of coastal fisher women through seaweed (Kappaphycus alvarezii (Doty) Doty) farming in Tamil Nadu, India. J Appl Phycol 26:775-781

Phipps L (2020) Algae is the plant-based, nontoxic alternative to plastic. https://www.brinknews.com/algae-is-the-plant-based-nontoxicalternative-to-plastic-sustainability-environment-climate/ (Accessed Jun 18, 2020)

Rajauia G (2015) Seaweeds: a sustainable feed source for livestock and aquaculture. In: Tiwari BK, Troy DJ (eds) Seaweed sustainability. Food and Non-food Applications. Academic Press, New York, pp $389-420$ 
Rajendran N, Puppala S, Sneha RM, Raj S, Ruth Angeeleena BR, Rajam C (2012) Seaweeds can be a new source for bioplastics. J Pharm Res 5:1476-1479

Ramachandra TV, Hebbale D (2020) Bioethanol from macroalgae: prospects and challenges. Renew Sust Energy Rev 117:109479

Rhatigan P (2009) Irish seaweed kitchen. Booklink, Co Down, Ireland

Rhatigan P (2018) Irish seaweed Christmas kitchen. Booklink, Co Down

Roque BM, Brooke CG, Ladau PJT, Marsh LJ, Najafi N, Pandey P, Singh L, Kinley R, Salwen JK, Eloe-Fadrosh E, Kebreab E, Hess M (2019) Effect of the macroalgae Asparagopsis taxiformis on methane production and rumen microbiome assemblage. Animal Microbiome 1:3

Rosa CP, Tavares WR, Sousa PMC, Pagès AK, Seca AML, Pinto DCGA (2020) Seaweed secondary metabolites with beneficial health effects: an overview of successes in in vivo studies and clinical trials. Mar Drugs 18:8

Sanford FB (1958) Seaweeds and their uses. United States Department of the Interior. Fishery Leaflet 469, Washington DC, 23

Sauvageau C (1920) Utilisation des alges marines. Gaston Doin et Cie, Paris

Schepers M, Martens N, Tiane A, Vanbrabant K, Liu HB, Lütjohann D, Mulder M, Vanmierlo T (2020) Edible seaweed-derived constituents: an undisclosed source of neuroprotective compounds. Neural Regen Res 15:790-795

Schmidt CV, Mouritsen OG (2020) The solution to sustainable eating is not a one-way street. Front Psychol 11:531

Schwimmer M (1955) The role of algae and plankton in medicine. Grune $\&$ Stratton, New York

Searchinger T, Waite R, Hanson C, Ranganathan J, Dumas P, Matthews E (2019) World resources report: creating a sustainable food future. A menu of solutions to feed nearly 10 billion people by 2050 . World Resources Institute, Washington

Selvaggi G, Monstrey S, Van Landuyt K et al (2003) The role of iodine in antisepsis and wound management: a reappraisal. Acta Chirurgica Belgica 103:241-247

Shafiq SA, Kamal SB, Mohammed ST, Mohammed N, Abdulkhaliq RJ (2018) Efficiency of seaweed extract of brown algae Ascophyllum nodosum against Leishmania donovani parasite. Plant Arch 18: $2252-2256$

Shannon E, Abu-Ghannam N (2019) Seaweeds as nutraceuticals for health and nutrition. Phycologia 58:563-577

Sharifuddin Y, Yao-Xian Chin YX, Lim PE, Phang SM (2015) Potential bioactive compounds from seaweed for diabetes management. Mar Drugs 13:5447-5491

Siah WM, Aminah A, Ishak A (2015) Edible films from seaweed (Kappaphycus alvarezii). Int J Food Res J 22:2230-2236

Smith EF (1926) Bromine and its discoverers-1826-1926. J Chem Ed 3: 382-384

Smith SV (1981) Marine macrophytes as a global carbon sink. Science 211:838-840
Sonali P, Kumar DN (2020) Review of recent advances in climate change detection and attribution studies: a large-scale hydroclimatological perspective. J Water Climate Change 11:1-29

Steffen W, Richardson K, Rockstrom J (2015) Sustainability. Planetary boundaries: guiding human development on a changing planet. Science 347:1259855

Teas J, Pino S, Critchley A, Braverman LE (2004) Variability of iodine content in common commercially available edible seaweeds. Thyroid 14:836-841

United Nations (2019) Sustainable Development Goals. https://www.un. org/sustainabledevelopment/sustainable-consumptionproduction/ (Accessed Apr 27, 2020)

Uris L (1976) Trinity. Doubleday, New York

Vermeulen SJ, Campbell BM, Ingram JSI (2012) Climate change and food systems. Annu Rev Environ Resour 37:195-222

Waters TJ, Lionata H, Prasetyo Wibowo T, Jones R, Theuerkauf S, Usman S, Amin I, Ilman M (2019) Coastal conservation and sustainable livelihoods through seaweed aquaculture in Indonesia: a guide for buyers, conservation practitioners, and farmers, Version 1. The Nature Conservancy. Arlington VA, USA and Jakarta, Indonesia

WHO (World Health Organization) (2007) Iodine deficiency in Europe: a continuing public health problem. https://www.ign.org/document. cfm?page_id=142003233 (Accessed May 07, 2020)

Willett W, Rockström J, Loken B, Springmann M, Lang T, Vermeulen S, Garnett T, Tilman D, DeClerck F, Wood A, Jonell M, Clark M, Gordon LJ, Fanzo J, Hawkes C, Zurayk R, Rivera JA, de Vries W, Majele Sibanda L, Afshin A, Chaudhary A, Herrero M, Agustina R, Branca F, Lartey A, Fan S, Crona B, Fox E, Bignet V, Troell M, Lindahl T, Singh S, Cornell SE, Srinath Reddy K, Narain S, Nishtar S, Murray CJL (2019) Food in the Anthropocene: the EAT-Lancet Commission on healthy diets from sustainable food systems. Lancet 393:447-492

Woodham-Smith C (1962) The Great Hunger: Ireland 1845-1849. Penguin, London

Woodward FN (1965) The seaweed industry of the future. In: Young EG, McLachlan JL (eds) Proceedings of the fifth International Seaweed Symposium, Halifax, Canada, August 25-28. Pergamon Press, Oxford, pp 55-70

Zalasiewicz J, Waters CN, Sul JI, Corcoran PL, Barnosky AD, Cearreta A, Edgeworth M, Gałuszka A, Jeandel C, Leinfelder R, McNeill JR, Steffen W, Summerhayes C, Wagreich M, Williams M, Wolfe AP, Yasmin Yonan Y (2016) The geological cycle of plastics and their use as a stratigraphic indicator of the Anthropocene. Anthropocene 13:4-17

Zhanga C, Showb P-L P, Hoa S-H (2019) Progress and perspective on algal plastics - a critical review. Biores Technol 289:121700

Zimmermann MB (2009) Iodine deficiency. Endocr Rev 30:376-408

Publisher's note Springer Nature remains neutral with regard to jurisdictional claims in published maps and institutional affiliations. 